\begin{tabular}{|c|c|c|c|c|}
\hline & \multicolumn{4}{|c|}{$\Phi=\frac{\text { moles liberated } / \text { c.c. } / \mathrm{hr}}{\text { einsteins absorbed } / \text { c.c. } / \mathrm{hr}}$. } \\
\hline & Gas* & Ammonia & Amino- & Total $\Phi$ \\
\hline $\begin{array}{l}\text { Phenylpro- } \\
\text { pionyl- } \\
\text { alanine }\end{array}$ & $\begin{array}{l}\text { Oxygen } \\
\text { Nitrogen }\end{array}$ & $\begin{array}{l}6.3 \times 10^{-3} \\
5.0 \times 10^{-3}\end{array}$ & $\begin{array}{l}0.65 \times 10^{-3} \\
0.12 \times 10^{-8} \\
\end{array}$ & $\begin{array}{l}6.95 \times 10^{-3}(a) \\
5.12 \times 10^{-3}\end{array}$ \\
\hline $\begin{array}{l}\text { Propionyl- } \\
\text { phenylalanine }\end{array}$ & $\begin{array}{l}\text { Oxygen } \\
\text { Nitrogen }\end{array}$ & $\begin{array}{l}5 \cdot 8 \times 10^{-3} \\
4.5 \times 10^{-3}\end{array}$ & $\begin{array}{l}0 \\
0\end{array}$ & $\begin{array}{l}5.8 \times 10^{-3}(b) \\
4.5 \times 10^{-3} \quad(b)\end{array}$ \\
\hline
\end{tabular}

* Irradiation in air gave the same results as under oxygen.

(a) This value is in good agreement with the determinations of Levy (refs. 9 and 10).

(b) A comparative study of the photolysis of phenylalanine under the same experimental conditions gave quantum yields of the same order of magnitude.

determined on the basis of the ammonia split off. Under nitrogen, all quantum yields are somewhat lower than under oxygen. Considerable changes in ultra. violet absorption spectra before and after irradiation were recorded in all cases, but Millon tests (tyrosine, 'Dopa') were negative and all solutions remained colourless. Reduction of ammoniacal silver nitrate solution and positive Eegriwe reaction (aldehyde, hydroxy- or keto-acid) were observed.

An interesting corollary of this study is the similarity between the low quantum yields of the model substances and those of intact enzymes and proteins ${ }^{11}$ INES MANDL A. D. McLaren

Institute of Polymer Research,

Polytechnic Institute of Brooklyn, New York.

May 18.

${ }^{1}$ Mitchell, J. S., Proc. Roy. Soc., A, 155, 696 (1936) ; Nature, 137, 509 (1936)

'Pauling, L., and Niemann, C., J. Amer. Chem. Soc., 61, 1860 (1939). See also Rideal, E. K., and Mitchell, J. S., Proc. Roy. Soc., A, 159,
206 (1937).

${ }^{3}$ Carpenter, D. C., J. Amer. Chem. Soc., 62, 289 (1940).

4 Van Slyke, D. D., Dillon, R. T., MacFayden, D. A., and Hamilton P.. J. Biol. Chem., 141, 627, 671 (1941).

${ }^{5}$ Carpenter, D. C., J. Franklin Inst., 232, 76 (1941).

- Abderhalden, E., and Haas, R., $Z$. physiol. Chem., 155, 202 (1926). Eckstein, H. C., and Lieben, F., Biochem. Z, 263, 366 (1933) Guillaume, A., and Tanret, G. C.R Acad Sci. Paris, 201,1057 (1935); Bull.' soc. chim. biol., 18, 556 (1936).

"Weizmann, C., Hirshberg, Y.; and Bergmann, E., J. Amer. Chem. Soc., 60, 1799 (1938)

'Allen, A. J., Steiger, R. E., Magill, M. A., and Franklin, R. G. Biochem. J., 31, 195 (1937).

- Levy, B., M.S. Thesis, Polytechnic Inst., Brooklyn (1948).

10 eLaren, A. D., and Pearson, S., J. Polymer Sci., 4, 45 (1949).

"McLaren, A. D., in "Advances in Enzymology" (Interscience, N.Y. vol. 9 , in the press).

\section{Bond Distances in Adenine Hydrochloride}

IN a recent crystallographic study of adenine hydrochloride, Broomhead ${ }^{1}$ has concluded that the central or $\mathrm{C}_{4}-\mathrm{C}_{5}$ bond distance of $1.44 \mathrm{~A}$. is probably significantly greater than those of the other $\mathrm{C}-\mathrm{C}$ or $\mathrm{C}-\mathrm{N}$ bonds in the molecule. This conclusion is based on two-dimensional Fourier projections and, as the author states, it is not absolutely certain that the discrepancy cannot be attributed to experimental error. Nevertheless, the result appears to be in accordance with the anomalous second dissociation constant which I have observed ${ }^{2}$, namely, $p K^{\prime} a_{1}=$ $4 \cdot 15, p K_{a_{2}}^{\prime}=9 \cdot 80$. The former value is of the order to be expected for the amino-group, but the latter, which can only be attributed to the - NH- group of the iminazole ring, is considerably lower than those observed for the corresponding dissociations in benziminazole and in other purine derivatives.

The unusual acidic strength of this group in adenine could be explained if considerable contributions to the structure of the molecule were made, not only by uncharged structures of types I and II, but also by others of types III and IV, in which there is a negative charge on the pyrimidine nitrogen atoms and a positive charge on those in the iminazole ring. This would lower $p K_{\alpha_{2}}^{\prime}$ from a value characteristic of an uncharged - NH - group towards one characteristic of a charged group $-\mathrm{NH}^{+} \mathrm{H}=$; respective values in the case of benziminazole are $12 \cdot 3$ and $5 \cdot 30$, and the observed value of $\mathbf{9 . 8 0}$ in adenine could thus be accounted for. Structures of types III and IV
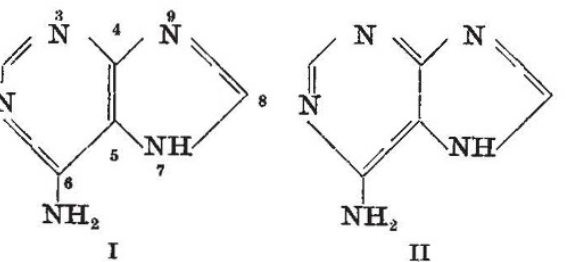

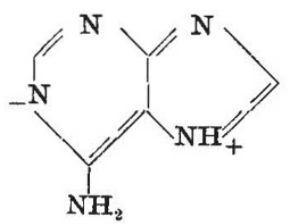

IV

I to IV, adenine

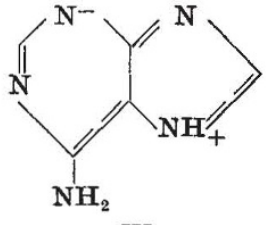

III necessarily contain a single bond in the $\mathrm{C}_{4}-\mathrm{C}_{5}$ position, and thus account qualitatively for the observed lengthening of the bond.

In the case of purines such as guanine in which oxygen atoms are attached to the pyrimidine ring, the dissociation of the iminazole - NH - group takes place in a molecule which already bears a negative charge in the region of the pyrimidine nitrogen atoms as a result of the dissociation of the $-\mathrm{NH}-\mathrm{CO}-$ or $-\mathrm{N}=\mathrm{C}(\mathrm{OH})-$ grouping. Structures corresponding to III and IV would thus be expected to make a smaller contribution to the state of the negatively charged molecule (V) than in the case of neutral or positively charged adenine. In accordance with this view, the $p K_{a}^{\prime}$ values of the iminazole $-\mathrm{NH}-$ groups in guanine and similar compounds are of the same order as in benziminazole. If this theory is correct, the $\mathrm{C}_{4}-\mathrm{C}_{5}$ bond distances of the negatively charged molecules existing in solution or as sodium salts should be of normal length. It is possible, how. ever, that when the $-\mathrm{NH}-\mathrm{CO}-$ grouping is undissociated, as in neutral guanine, or its hydrochloride, the bond distances may be influenced by the different charge distribution. The results of the current X-ray studies mentioned by Broomhead ${ }^{\lambda}$ will be of con. siderable interest.

\section{H. F. W. TAYLOR}

Birkbeck College Research Laboratory,

21 Torrington Square,

London, W.C.I.

March 31.

1 Broomhead, Acta. Cryst., 1, 324 (1948).

'Taylor, J. Chem. Soc., 765 (1848). 